\title{
Oil and gas cooperation between China and Central Asia in an environment of political and resource competition
}

\author{
Hu Bin ${ }^{1,2 *}$ \\ ${ }^{1}$ College of Petroleum Engineering, China University of Petroleum, Beijing 102249, China \\ ${ }^{2}$ The Planning Department, China National Petroleum Corporation (CNPC), Beijing 100008, China \\ (C) China University of Petroleum (Beijing) and Springer-Verlag Berlin Heidelberg 2014
}

\begin{abstract}
This paper investigates Central Asia's oil and gas resources, special geopolitics and energy competition, and approaches, challenges and prospects in cooperation between China and Central Asia. The objective is to propose measures for oil and gas cooperation between China and Central Asia. Central Asia is rich in oil and gas resources. Its remaining recoverable reserves of crude oil and natural gas account for $1.9 \%$ and $10.6 \%$, respectively, of the world's total reserves. Moreover, there is great exploration and development potential. As a strategic channel connecting Eurasia, Central Asia has a prominent geopolitical status. Many powerful countries such as the United States, Russia and China, as well as Europe, have an intense energy competition in Central Asia. In the oil and gas cooperation with Central Asia, the China National Petroleum Corporation (CNPC) focuses on establishing a coordination group, promoting overall oil and gas business opportunities and sustainable development, innovating and applying specialty engineering technology and improving project economic benefits. Through its efforts over the last nearly two decades, the China National Petroleum Corporation has completed a 50-million-tonne a year oil and gas production centre in Central Asia and oil and gas pipelines passing through multiple countries, becoming an important channel for securing China's energy imports. If appropriate measures are taken in the 'Thirteenth Five-Year Plan' period or later, the China National Petroleum Corporation will develop a 100-million-tonne p.a. oil and gas production centre in Central Asia and a strategic oil and gas import channel exceeding this amount of production. This cooperation between China and Central Asia is however faced with the following challenges: increasing multinational competition uncertainty, potential risks in the political systems of Central Asian countries, frequently occurring violence and also resource policy tightening in Central Asia. To further oil and gas cooperation with Central Asia, it is recommended that China should develop an energy acquisition strategy, assign a regional energy ambassador, enhance oil and gas supply by mergers and acquisitions, establish regional multinational subsidiaries and improve its risk prevention system.
\end{abstract}

Key words: Central Asia, oil and gas, cooperation, competition, energy channels, oil and gas production centre, mode, innovation, proposal

\section{Introduction}

Central Asia commonly refers to the vast area of five countries: Kazakhstan, Uzbekistan, Kyrgyzstan, Turkmenistan and Tajikistan (Wang, 2012). Bordering Russia in the north and west, China in the east, Iran and Afghanistan in the south, and the Caspian Sea in the west. Central Asia has an extremely significant strategic position. Central Asia is rich in mineral resources, one of the world's major oil and gas producing areas, a hub of the famous 'ancient Silk Road', and it serves as the starting point of the China-Central Asia

*Corresponding author. email: hubin003@cnpc.com.cn

Received June 13, 2014 transnational oil and gas pipeline.

Because of its strategic position and rich oil and gas resources, Central Asia is a major focus of competition for the world's political and economic powers. The United States, Russia, European Union (EU) and Japan have launched their respective Central Asian strategies in an attempt to expand their influence and gain a competitive advantage. As a close neighbour of the Central Asian countries, China pursues a foreign policy of 'building friendships and partnerships with neighbouring countries' (Zhao, 2012) with positive mutual benefits and pursues win-win cooperation with Central Asian countries.

Owing to its rapid economic development, China has great demands for energy. Still underdeveloped, Central 
Asia needs to export its rich oil and gas resources. In 2013, 11 million tonnes of crude oil, 27.7 billion cubic metres of natural gas and 34.5 million tonnes of oil equivalent (including gas) were transported to China through Central Asian oil and gas pipelines. On the basis of China-Central Asia oil and gas cooperation, China and Central Asia should further improve, promote, develop and expand this strategic partnership, which is of great strategic and geopolitical significance for the economic development of China and Central Asia, as well as for peace and stability in Asia and the rest of the world.

This paper analyses the oil and gas resource potential in Central Asia and the results of the China-Central Asia cooperation in the oil and gas industry. It explains Central Asia's geopolitical and resource competition and focuses on the necessary adjustments in terms of this cooperation, along with cooperative prospects and policy suggestions to strengthen the cooperation.

China-Central Asia oil and gas cooperation has been implemented and promoted almost entirely by the China National Petroleum Corporation (CNPC). This paper discusses and analyses this cooperation using CNPC as an example.

\section{Oil and gas resources in Central Asia}

Rich in oil and gas resources, Central Asia is known as 'the second Middle East' and 'the second Persian Gulf' (Wang, 2012). In Central Asia, there are 16 major sedimentary basins, including 10 basins producing oil and gas that are mainly distributed in the three countries bordering the Caspian Sea; namely, Kazakhstan, Uzbekistan and Turkmenistan, which occupy an important place in terms of the world's supply of oil and gas.

\subsection{Resources}

As of 2012, Kazakhstan, Turkmenistan and Uzbekistan had remaining recoverable reserves of crude oil amounting to $41 \times 10^{8}$ tonnes and $19.9 \times 10^{12}$ cubic metres of gas reserves, accounting for $1.9 \%$ and $10.6 \%$ of the world's remaining recoverable reserves respectively (Table 1). Moreover, there are greater undiscovered crude oil and gas resources, representing a huge potential for the oil and gas industry.

Table 1 Crude oil and gas resources in major Central Asian countries (BP statistical reviews, 2013)

\begin{tabular}{|c|c|c|c|c|c|c|}
\hline & \multicolumn{3}{|c|}{ Crude oil } & \multicolumn{3}{|c|}{ Natural gas } \\
\hline & $\begin{array}{l}\text { Undiscovered } \\
\text { resources, } 10^{8} \mathrm{t}\end{array}$ & $\begin{array}{l}\text { Remaining } \\
\text { recoverable } \\
\text { reserves, } 10^{8} \mathrm{t}\end{array}$ & $\begin{array}{c}\text { Proportion of } \\
\text { remaining } \\
\text { recoverable reserves } \\
\text { in the world's total } \\
\%\end{array}$ & $\begin{array}{l}\text { Undiscovered } \\
\text { resources } \\
10^{12} \mathrm{~m}^{3}\end{array}$ & $\begin{array}{c}\text { Remaining } \\
\text { recoverable } \\
\text { natural gas reserves } \\
10^{12} \mathrm{~m}^{3}\end{array}$ & $\begin{array}{c}\text { Proportion of } \\
\text { remaining } \\
\text { recoverable } \\
\text { reserves } \\
\text { in the world's total, \% }\end{array}$ \\
\hline Total & 109 & 41 & 1.9 & 32 & 19.9 & 10.6 \\
\hline Kazakhstan & 76 & 39 & 1.8 & 13 & 1.3 & 0.7 \\
\hline Turkmenistan & 8 & 1 & 0.05 & 15 & 17.5 & 9.3 \\
\hline Uzbekistan & 25 & 1 & 0.05 & 4 & 1.1 & 0.6 \\
\hline
\end{tabular}

Central Asian oil and gas resources are characterized by the following: 1) oil and gas resources are increasingly prevalent towards the west. Resources are mainly concentrated in the western region of Kazakhstan, Turkmenistan and Uzbekistan, where oil and gas account for $95.7 \%$ and $99.3 \%$ respectively of the total resources and proven reserves account for almost $100 \%$. Tajikistan and Kyrgyzstan in the east are relatively poor in oil and gas resources; and 2) oil resources are increasingly prevalent towards the north, while gas resources are increasingly prevalent towards the south. Kazakhstan in the north has abundant oil reserves, but is relatively low in gas reserves, while Turkmenistan in the south is rich in gas reserves, but relatively poor in oil reserves.

\subsection{Output}

In 2012, Kazakhstan, Turkmenistan and Uzbekistan had a crude oil output of $9,730 \times 10^{4}$ tonnes and gas output of $1,410 \times 10^{8}$ cubic metres, accounting for $2.4 \%$ and $4.2 \%$, respectively, of the world's total oil and gas output (Table 2). Kazakhstan had a high crude oil output, while Turkmenistan had a high gas output.

Table 2 Crude oil and gas output in major Central Asian countries (Zhao, 2012)

\begin{tabular}{|c|c|c|c|c|}
\hline & \multicolumn{2}{|r|}{ Crude oil } & \multicolumn{2}{|r|}{ Natural gas } \\
\hline & Output, $10^{4} \mathrm{t}$ & Proportion in the world's total, \% & Output, $10^{8} \mathrm{~m}^{3}$ & Proportion in the world's total, \% \\
\hline Total & 9730 & 2.4 & 1410 & 4.2 \\
\hline Kazakhstan & 8130 & 2.0 & 197 & 0.6 \\
\hline Turkmenistan & 1100 & 0.3 & 644 & 1.9 \\
\hline Uzbekistan & 320 & 0.1 & 569 & 1.7 \\
\hline
\end{tabular}




\section{Central Asia geopolitical and resource competition}

\subsection{Central Asia has prominent geopolitical status}

In the geopolitical map of the world, Central Asia is located in the 'oil heartland', because it is not only rich in oil and gas reserves but also serves as a strategic channel connecting Eurasia. In order to control energy around the Caspian Sea after the Cold War, a variety of political, economic, military, cultural and other forces have constantly enhanced their involvement and attempted to control Central Asia both politically and militarily; thus, affecting its economy and culture and creating worldwide competition for Central Asia and its resources (Liang, 2011).

\subsection{The fierce competition for Central Asian oil and gas resources}

In an effort to control the oil and gas resources and the strategic location of Central Asia, Russia has constantly promoted its 'Eurasian Union' programme to maintain its influence on Central Asia and control the export channels of the Central Asia oil and gas resources, getting positively involved in Central Asian oil and gas exploration and development on one hand, and secondly buying Central Asian natural gas with reference to European gas prices, cooperating with Kazakhstan and Turkmenistan in planning to construct a gas pipeline around the Caspian Sea, planning to invest 2 billion US dollars in transforming the Central Asian main pipeline system and directly impacting the pursuit of any Western nation natural gas pipeline plan.

The United States has proposed the 'New Silk Road' ('Great Central Asia Plan'), which clarifies its Central Asia energy strategy. First, the United States plans to split the energy interest 'cake' by encouraging and protecting American businesses that participate in Central Asian oil and gas resource development aimed at creating the greatest economic benefits and seeking new oil sources. Second, on the basis of geopolitical considerations, it plans to promote an oil and gas pipeline that bypasses Russia and breaks the Russian monopoly on the export of Central Asian oil and gas resources. Therefore, the United States is supporting the completion of the Baku-Ceyhan pipeline and the construction of a Kazakhstan oil pipeline across the Caspian Sea that will connect with the Baku-Ceyhan pipeline, so as to transport Kazakhstan and Turkmenistan oil through this pipeline system. The United States is also supporting the construction of a Kazakhstan and Turkmenistan gas pipeline across the Caspian Sea that will connect with the proposed Nabucco pipeline, so as to radically break Russia's control of Central Asia's oil and gas exports and to influence China's access to these resources.

The EU is vulnerable to its dependence on Russian oil and gas and the threat of cutting off the gas supply. Its oil and gas strategy focuses on introducing Central Asian oil and gas that bypasses Russia. In 1993, the EU launched the 'Interstate Oil and Gas to Europe Pipelines' (INOGATE), seeking export channels of Central Asian oil and gas to Europe. In 2002, it proposed to construct the Nabucco natural gas pipeline. In 2007, it signed the EU and Central Asia: Strategy for a New Partnership draft with Central Asia, planning to provide 750 million euros to Central Asian countries from 2007 to 2013. A part of these funds would be used to 'transform' the Central Asian countries in terms of human rights, democracy and legal systems, while another part would be used to modernize the Central Asian energy and transportation infrastructure.

In order to alleviate the shortage of oil and gas resources, reduce its dependence on the Malacca Strait shipping route and ensure its oil and gas supply, China has implemented 'going global' and import-channel diversification strategies. Considering factors like respecting the sovereignty of the resource countries, mutual benefits and obtaining win-win cooperation, China invested in the Central Asian countries by participating in the effective utilization of the oil and gas resources. Without involving any third party, China has partnered with Kazakhstan and constructed the ChinaKazakhstan oil pipeline and cooperated with Turkmenistan, Uzbekistan and Kazakhstan in constructing the Central Asian natural gas pipeline, Lines A and B. This project opened up China's strategic energy channel in the northwest, laying a solid foundation to diversify its energy import channels (Bo and Liu, 2012).

\subsection{Different responses of Central Asian countries}

For their own interests, the Central Asian countries are trying to reduce the control of Russia, especially by preventing Russia from bottlenecking their oil and gas exports. At the same time, these countries are trying to avoid becoming a 'disguised colony' of the western countries. To counter any further aggravation of the competition in Central Asia, the Central Asian countries carry out multiple balanced diplomacies with different focuses, rather than rely on any single external force. For example, Kazakhstan implements an 'all-round balanced and pragmatic diplomacy' that adheres to a positive, diverse and balanced foreign policy, where Russia, China and the United States are regarded as its first, second and third strategic partners, respectively. Turkmenistan pursues a neutral foreign policy, with particular emphasis on relations with Russia, Ukraine and other Commonwealth of Independent States (CIS) countries and pursues developing positive relations with the United States, China, Turkey and other countries. Uzbekistan attaches importance to developing relations with the major powers; therefore, its foreign policy swings between Russia and the United States. In recent years, it has carried out a more pragmatic and balanced diplomacy, attaching importance to relations with its neighbours in Central Asia and China.

\subsection{Chinese opportunities in the competition for Central Asia}

The main purpose of the US Central Asian strategy is to weaken the influence of Russia and China. However, the United States has needed the cooperation of China and Russia on the Afghanistan issue. Russia and the United States have a structural conflict in Central Asia (Gao, 2013). Russia does not want to make China's influence stronger but, at the same 
time, Russia needs China to counter American influence in Central Asia. The EU wishes the Central Asian oil and gas resources can be transported to Europe but, at the same time, the EU understands that peace and stability will not be maintained in Central Asia without China. In order to reduce their dependence on Russia and the influence of the United States and Europe, the Central Asian countries need China to achieve balance and for diversification. Therefore, in the Central Asian competition, China has many opportunities and great potential for achievement.

\section{Process and results of China-Central Asia oil and gas cooperation}

\subsection{Process of cooperation}

China-Central Asia oil and gas cooperation has experienced four stages starting from a single project and ending in regional cooperation.

The first stage (1997-2003): A single project of ongoing production, targeting economic benefits. On June 4, 1997, CNPC and the Kazakhstan Ministry of Finance signed a stock purchase agreement. CNPC purchased $60.3 \%$ of the stocks of Aktobe for 320 million US dollars. This was the first project that CNPC acquired in Central Asia, representing its 'going global' international energy cooperation landmark project. In September of the same year, CNPC and the Kazakhstan Ministry of Energy and Mines signed new oil contracts, and CNPC acquired development licenses for three oilfields. In 2002, Aktobe and CNPC signed the first Central Asia risk exploration contract. This period witnessed an increase in oil and gas prices. CNPC focused on Kenkiyak post-salt heavy oil reservoirs and pre-salt reservoirs and the Zhanazhol condensate oil and gas field drilling, as well as their technological development and economic benefits. CNPC also conducted detailed studies after obtaining the risk exploration blocks, but it failed to drill any exploratory wells.

The second stage (2003-2004): New projects for production increase and further cooperation. With the rise in oil prices, the results of Aktobe inspired CNPC to seek new projects. In Kazakhstan, it acquired NB in June, 2003, signed KAM and ADM stock purchase agreements and began to discuss a China-Kazakhstan crude oil pipeline in 2004. In June 2004, it signed agreements for the Silk Road exploration project, the Mingbulak oilfield exploration and development project and the Aral Sea waters joint exploration and development project, which was managed by five parties of the Aral Sea Investment Consortium in Uzbekistan. In this stage there was a specific focus on the Aktobe project, and it was characterized by mature technology and a constant rise in crude oil output.

The third stage (2005-2010): Merger of large projects and the construction of oil and gas pipeline infrastructure. CNPC acquired PK and Mangistau and invested in the Amu Darya Right Bank project in Turkmenistan. These three projects significantly increased the crude oil output. The China-Kazakhstan Crude Oil Pipeline Agreement was signed in 2005. In 2007, the Chinese government signed the natural gas pipeline agreement with Kazakhstan, Uzbekistan and Turkmenistan. Pipeline infrastructure was vigorously expanded and the strategic importance of Central Asian oil and gas cooperation was highlighted.

The fourth stage (2011-present): Oil and gas cooperation rapidly improved, as well as the scale of oil and gas pipeline construction. In 2011, the Central Asian natural gas pipeline began to transport gas to China and the Amu Darya Right Bank project output rose rapidly. In 2011, Central Asian cooperation resulted in an oil and gas equivalent of 34.1 million tonnes, accounting for 34\% of the 'overseas Daqing', where the equity output accounted for $44 \%$. The ChinaKazakhstan Crude Oil Pipeline (a 20 million tonne p.a. transportation project); the Central Asia pipeline, Lines $\mathrm{A}$ and $\mathrm{B}$, booster stations; and the Central Asia pipeline, Line $C$, were all under vigorous construction and Central Asian strategic channel planning targets were gradually implemented.

\subsection{Experience of cooperation}

\subsubsection{Establishing the Central Asian coordination group to promote oil and gas cooperation and sustainable development}

In 2010, CNPC established the Central Asian operation and coordination group, whose objectives were integrating public resources, sharing oil and gas information, coordinating energy policy, optimizing the allocation of resources, guiding project investment and gradually forming a public relation system characterized by unified coordination and clear divisions of responsibility. On the one hand, this group focuses on overall planning but different national conditions are also taken into account to reduce conflict in the national interest; on the other hand, this group conducts unified planning and operations for different businesses, services and companies and maximizes CNPC's benefits. Its main practices are as follows: 1) strengthening the coordination among the governments of countries hosting the resources; 2) establishing transnational coordination mechanisms; and 3 ) ensuring the coordination of resource development and the construction of strategic channels.

4.2.2 Innovatively applying specialty engineering technology and improving project economic benefits

In cooperation with the Central Asian countries in oil and gas projects, CNPC has made full use of the overall advantages of domestic oil and gas exploration and development by introducing specialty domestic engineering, technical support and service teams; combining mature domestic engineering technical support systems and Central Asian research talents. This includes integrating, innovating and forming practical supporting engineering technical systems; improving single-well output, maintaining stable production, slowing the decline in production through creative specialty and technologies and achieving significant economic benefits from the projects in operation.

In a project, CNPC implemented three strategies; horizontal wells, water injection and recovery efficiency enhancement, trying to inject water of good quality and great quantity. It focused on drilling new injection wells, 
transferring and adjusting water injection and sidetrack drilling horizontal wells flowing back layer that improve the injection well network and water flooding control and maintain high formation pressures. Significant results were achieved after implementation. The main oilfield well opening rate increased to more than $90 \%$; the Oilfield $\mathrm{K}$ drilling cycle had a year-on-year reduction of 5 days, while Oilfield $Z$ had a year-on-year reduction of 13 days; the pump-check period of Oilfield K was extended from 278 to 360 days, whereas that of Oilfield $\mathrm{Z}$ increased from 121 to 125 days; and optimized lifting work systems were applied to 1,114 wells over 2.5 years, which increased oil production by 132 tonnes per well and accumulated overall oil production by 150,000 tonnes. Within 2.5 years after CNPC took over the project, more than 2 million tonnes of extra crude oil were produced, compared with the initial predicted evaluation upon acquisition (Fig. 1), with huge economic benefits.

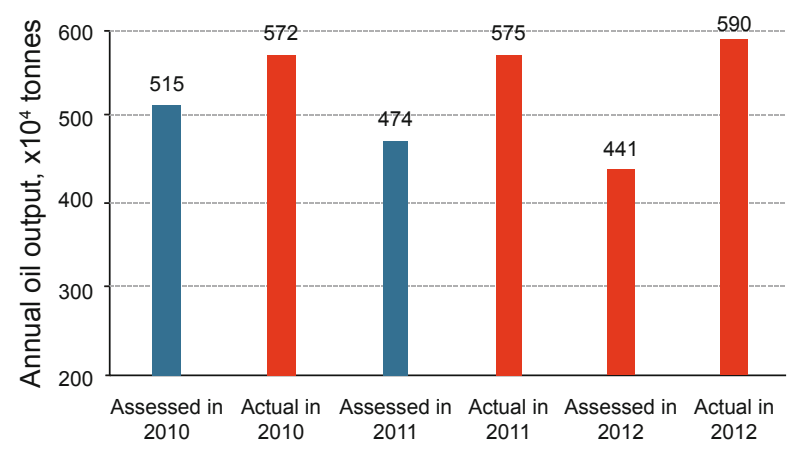

Fig. 1 A project evaluation and comparison with actual oil production

The Turkmenistan gas field is characterized by high pressure, high temperature, high sulphur content, high chloride, high carbon dioxide and high output. As a result, CNPC has integrated the application of new technologies, processes and materials; using ten drilling supporting technologies, shortening the average drilling cycle from 565 to 120 days and creating seven Turkmenistan drilling records, including the success of the first high-angle directional well and horizontal well completions, the shortest well construction period for wells of 5,000 metres or deeper, a $100 \%$ cementing quality passing the salt layer and in high-pressure gas reservoirs and a $100 \%$ drilling success rate. In its natural gas development, CNPC has improved the well network by optimizing the well types, deploying horizontal/high-angle wells at the boundary, fully utilizing the potential of different reservoirs and increasing the annual gas production capacity from 4 billion cubic metres to 6.5 billion cubic metres (up 63\%). CNPC has adopted innovative applications of new technologies, such as clean self-reversion acidification and hole patching, that have greatly improved single-well outputs, making the average unimpeded flow of the old wells 3.5 times that of the original programme (Fig. 2). Such applications have also increased the single well average daily output from 400,000 cubic metres to over 800,000 cubic metres, reduced the total number of planned gas wells from 48 to the currently implemented 33 wells (a reduction of $31 \%$ ) and reduced the average investment of the 100 million cubic metre field capacity by $12 \%$ compared with the domestic gas fields. In terms of construction projects, CNPC has strengthened its technology research, equipment and piping material selections to form ten newly advanced technologies, nine integrated technologies and eight patented technologies. CNPC has vigorously promoted indoor prefabrication and onsite assembly, improved the construction accuracy, reduced the production costs and shortened the construction period. The Amu Darya Right Bank gas field achieved 'higher output and higher efficiency from fewer wells, making its total single-well output and gas field capacity double that of the former Soviet Union programme (Wang, 2012).

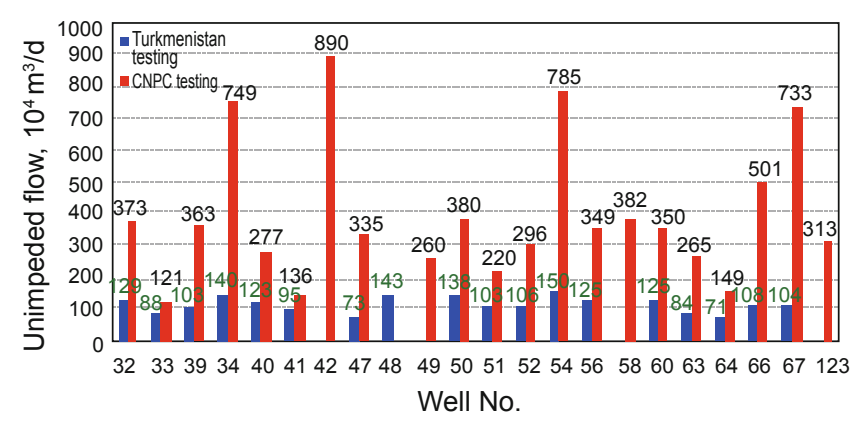

Fig. 2 Comparison of the effects of different techniques in gas field testing in the Amu Darya Right Bank field

\subsection{The main results of cooperation}

4.3.1 Developing three oil producing areas and two gas producing areas to initially form a 50 million tonne p.a. oil and gas production centre in Central Asia

CNPC has increased Central Asian crude oil output from $263 \times 10^{4}$ tonnes in 1997 to $2,423 \times 10^{4}$ tonnes in 2011 (up nearly 10 times), gas output from $7 \times 10^{8}$ cubic metres in 1997 to $123 \times 10^{8}$ cubic metres in 2011 (up 17 times) and total oil equivalent production from $300 \times 10^{4}$ tonnes in 1997 to $3,400 \times 10^{4}$ tonnes in 2011 (up more than 10 times). By the end of 2011, the CNPC Kazakhstan Company had $4.65 \times 10^{8}$ tonnes of remaining recoverable oil reserves, $3,494 \times 10^{4}$ tonnes of gas condensate and $2,140 \times 10^{8}$ cubic metres of natural gas. The Turkmenistan Amu Darya Right Bank Project had remaining recoverable gas reserves of $3,743 \times 10^{8}$ cubic metres, growing at an average annual rate of $(400-500) \times 10^{8}$ cubic metres (Wang, 2012). In Central Asia, CNPC has basically developed three oil producing areas in Kazakhstan (Aktobe, Qyzylorda and Aktau) and two gas producing areas in Turkmenistan (Amu Darya) and Uzbekistan (Karakuri) (Fig. 3), which have an annual output of 50 million tonnes of oil equivalent.

4.3.2 Completing the multinational oil and gas pipelines, which serve as the most important and secure energy import channel in China

In crude oil pipeline construction, the China-Kazakhstan Crude Oil Pipeline, Stage 1, Atasu-Alataw Pass section, has a total length of 965 kilometres, and it transported oil in the same year of construction. The Stage 2, Kenkiyak-Kumkol 


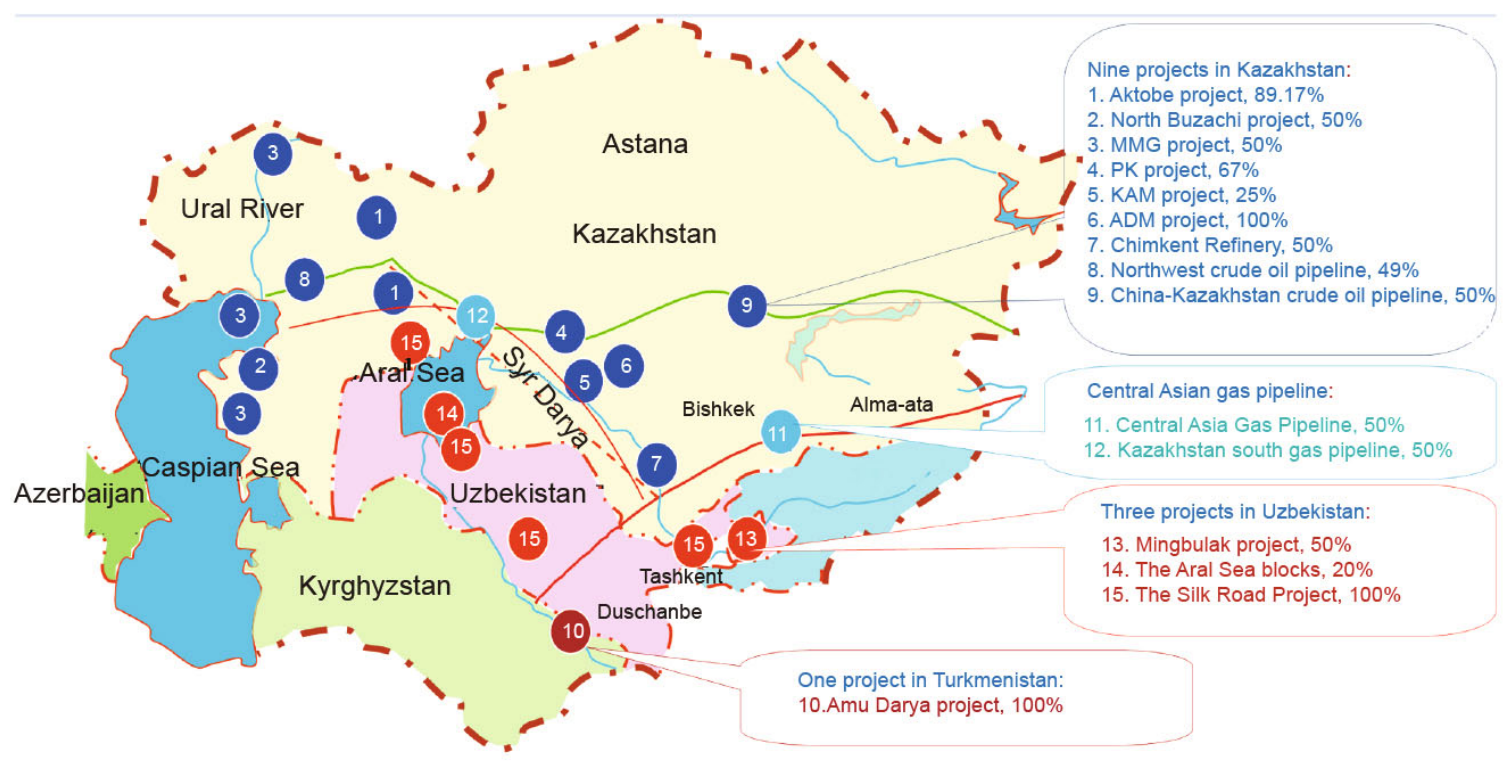

Fig. 3 Distribution of CNPC's Central Asian oil and gas cooperation projects

section has a total length of 794 kilometres and it was completed within just 14 months, creating a world record in crude oil pipeline construction. The pipeline connects China and the Caspian Sea oil producing areas and it has increased its initial capacity from 12 million tonnes per annum to 20 million tonnes per annum by the end of 2013 .

In terms of the Central Asian natural gas pipeline construction from July 17, 2007 (when the Agreement on China purchasing gas from Turkmenistan was signed) to December 2009, CNPC had completed the double-laid gas pipeline across four countries. The pipeline has an annual gas transport capacity of 30 billion cubic metres, a singleline length of 1,833 kilometres and a pipeline diameter of
1,067 millimetres. This project was completed within just 28 months (from a feasibility study to being put into operation), creating the 'Amu Darya miracle' in pipeline construction. As of June 10, 2012, 30 billion cubic metres of gas had been transported to China. The Central Asia Natural Gas Pipeline, Line C, was started in 2012, put into operation at the end of 2013 and will achieve a gas transport capacity of 25 billion cubic metres with a pipe diameter of 1,067/1,219 millimetres by the end of 2015. So far, the Kazakhstan 'West-East Gas Transfer' South Kazakhstan line has started its operations, with a design capacity of 5-10 billion cubic metres per year, a pipeline diameter of 1,067 millimetres and a length of 1,130 kilometres. It was put into production in 2013 (Fig. 4).

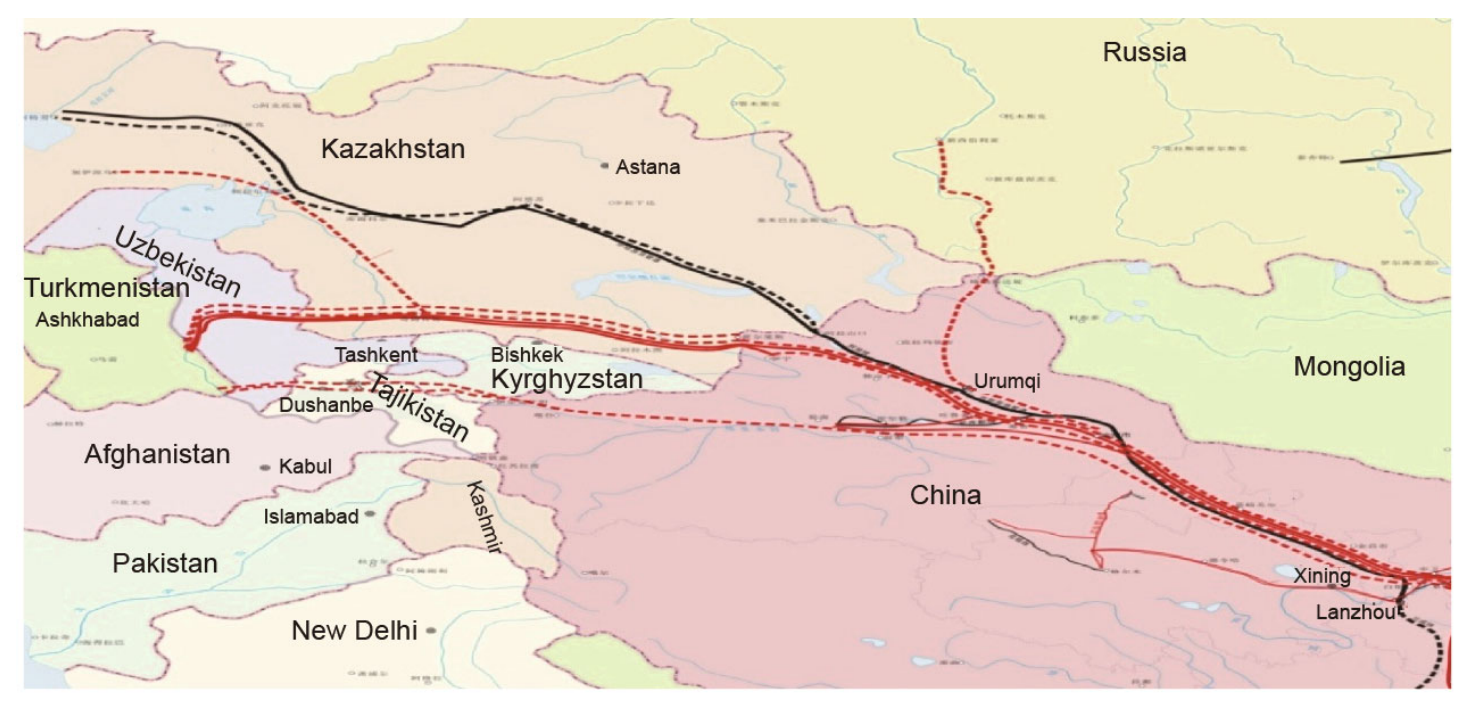

Fig. 4 Chinese-Central Asian oil and gas pipeline planning diagram

Notes: The red lines are natural gas pipelines, and black are crude oil pipelines, the solid lines are completed pipelines while the dotted lines are pipelines under construction. 
It is estimated that 20 million tonnes of crude oil and 55 billion cubic metres of natural gas will be transported to China through this energy channel in 2015, accounting for $7 \%-9 \%$ of China's total oil imports and $70 \%$ of China's total natural gas imports, effectively increasing the ability to protect Chinese oil and gas supplies (He, 2013).

4.3.3 Forming a transnational business mode through innovation and serving as a 'going global' model for the state-owned enterprises

Since 1997, CNPC has constantly improved its approach in business practice overseas, forming a specialty multinational business mode through innovation in Central Asia; namely, the Central Asian oil and gas cooperation mode. This mode includes the following: referring to the successful experience of international oil companies; retaining unique political advantages different from other international oil companies; introducing advanced management tools and management philosophy; localization; and using professional experts of international oil companies in combination with practical situations based on organisational restructuring, departmental function definitions, fixed staffing, workflow arrangements and management system improvements. In addition, a scientific and standardized management system characterized by regional multinational oil company management and operation mechanisms, in accordance with international practice, has been established, including the 'international management mode' represented by the PK project, the 'localization management mode' represented by the Aktobe project, the 'equal-power management mode' represented by the Mangistau project, the 'EPC management operation mode' represented by the Amu Darya Right Bank project and 'general contracting organisation mode' of CNPC Chuanqing represented by the Galkynysh project (Fig. 5).

CNPC was one of the first state-owned Chinese enterprises that responded to the national call of 'going global'. With its results in terms of Central Asian oil and gas cooperation, it has made significant contributions to the security of the national oil and gas supply and it has achieved good economic benefits; thus setting itself up as an successful example for other state-owned enterprises in terms of 'going global'.

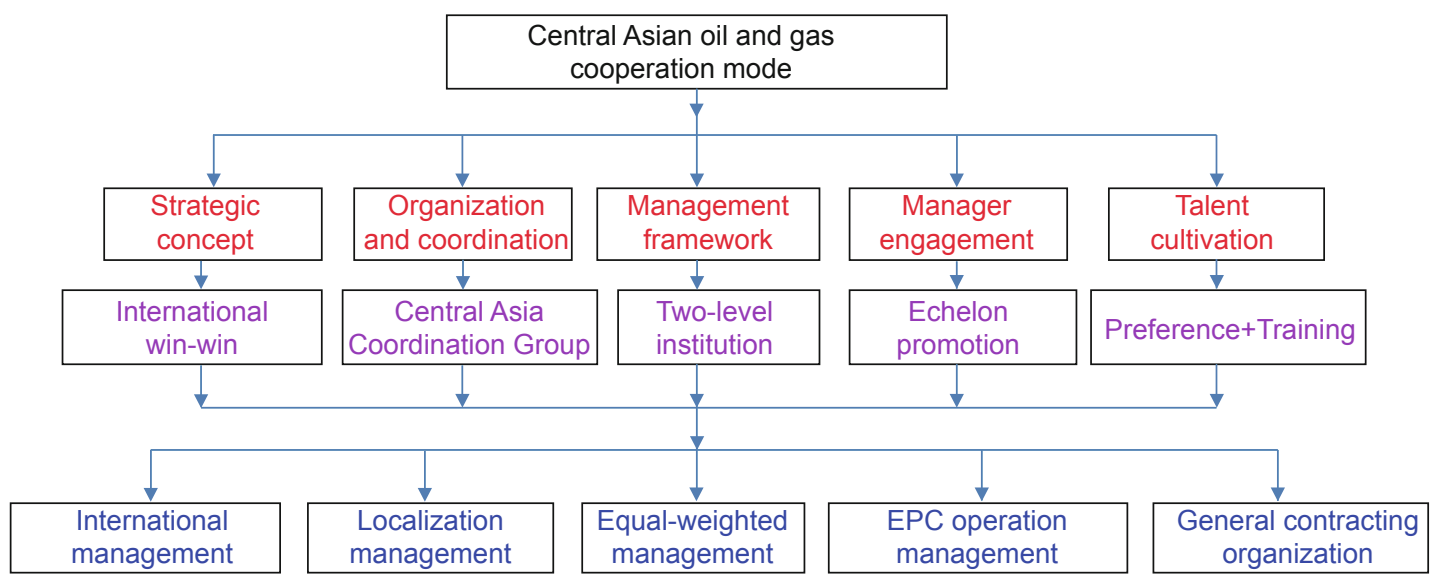

Fig. 5 Central Asian oil and gas cooperation mode diagram

\section{China-Central Asia oil and gas cooperation prospects and adjustments}

\subsection{Analysis of the prospects}

Central Asian oil and gas cooperation is an overseas Chinese objective that has been nurtured and developed for many years. In 1997, CNPC obtained the Aktobe project and began a 12-year entrepreneurship programme. In 2009, from Central Asia CNPC had an oil equivalent production of more than 30 million tonnes, accounting for 34\% of China's total overseas oil output and $44 \%$ of its equity output and achieving an integrative development. It is the CNPC project in Central Asia that possesses the most important and strongest strategic position overseas, and it includes the most complete business chain and generates the greatest cash contributions.

According to the agreements reached between China and the Central Asian countries and the construction schedule of the oil and gas import channel, it is estimated that Central Asian oil and gas exports to China in 2015 will include 20 million tonnes of crude oil and 4-10 billion cubic metres of natural gas from Kazakhstan, 41 billion cubic metres of natural gas from Turkmenistan and 10 billion cubic metres of natural gas from Uzbekistan for a total oil and gas equivalent of 70 million tonnes or approximately $20 \%$ of total China's domestic oil and gas production.

According to relevant research and forecasts, the five Central Asian countries will increase their oil production from $0.97 \times 10^{8}$ tonnes in 2011 to $1.47 \times 10^{8}$ tonnes in 2020 and to $2 \times 10^{8}$ tonnes in 2030 ; increase their crude oil exports from $0.77 \times 10^{8}$ tonnes to $1.2 \times 10^{8}$ tonnes in 2020 and to $1.5 \times 10^{8}$ tonnes in 2030; increase their natural gas production from $1,366 \times 10^{8}$ cubic metres in 2011 to $(1,600-1,800) \times 10^{8}$ cubic metres in 2020 and to $(2,300-2,500) \times 10^{8}$ cubic metres in 2030 and increase their natural gas exports from $525 \times 10^{8}$ cubic metres to $1,000 \times 10^{8}$ cubic metres in 2020 and to $(1,500$ $1,600) \times 10^{8}$ cubic metres in 2030 (IEA, 2010; Kou, 2010) (see Table 3). Considering the demand for oil and gas in the Central Asian countries themselves as a result of their economic development, the multinational competition for 
energy, national politics and oil and gas export policy in each country, crude oil exports to China from the five Central Asian countries will increase from $0.12 \times 10^{8}$ tonnes in 2011 to $0.20 \times 10^{8}$ tonnes in 2015 and to $0.40 \times 10^{8}$ tonnes in 2020 and $0.60 \times 10^{8}$ tonnes in 2030 . Natural gas exports to China will increase from $250 \times 10^{8}$ cubic metres in 2012 to $(700-800) \times 10^{8}$ cubic metres in 2020 and to $1000 \times 10^{8}$ cubic metres in 2030 . It is predicted that the five Central Asian countries' oil and gas exports to China in 2020 will be about $1.1 \times 10^{8}$ tonnes oilequivalent and about $1.4 \times 10^{8}$ tonnes in 2030 (Mao, 2013), accounting for $24 \%$ of China's total oil and gas imports $\left(4.5 \times 10^{8}\right.$ tonnes $)$ in 2020 and $23 \%\left(6.0 \times 10^{8}\right.$ tonnes $)$ in $2030^{1}$.

Table 3 Forecast Central Asian oil and gas output and exports (IEA, 2010; Kou, 2010)

\begin{tabular}{cccccc}
\hline \multirow{2}{*}{ Year } & \multicolumn{2}{c}{ Oil, $\times 10^{8} \mathrm{t}$} & & \multicolumn{2}{c}{ Natural gas, $\times 10^{8} \mathrm{~m}^{3}$} \\
\cline { 2 - 3 } \cline { 5 - 6 } & Output & Exports & & Output & Exports \\
\hline 2011 & 0.97 & 0.77 & & 1366 & 525 \\
2020 & 1.47 & 1.2 & & $1600-1800$ & $1000-1100$ \\
2030 & 2.0 & 1.5 & & $2300-2500$ & $1500-1600$ \\
\hline
\end{tabular}

Therefore, the Chinese government and CNPC have to take comprehensive and effective measures in the 'Thirteenth Five-Year Plan' period or later to ensure that China will develop a 100 million tonnes p.a. oil and gas production centre and a strategic pipeline channel in Central Asia that can transport over 100 million tonnes each year to China and achieve the safest, most convenient and most important energy import channel in order to meet the country's needs for oil and gas and to promote energy safety ${ }^{1}$.

\subsection{Challenges faced by cooperation}

\subsubsection{Increasing the uncertainty of multinational political and economic competition}

Central Asia is characterized by rich oil and gas resources and a unique geostrategic position, so the world's powers spare no effort to compete for Central Asian energy. 'Multinational wrestling, internal and external competition' is the new feature of the Central Asian energy geopolitical structure. The United States, Russia, EU and China have been involved in the competition. The United States is ensuring that the completed Baku-Ceyhan pipeline will have sufficient oil supplies by promoting the implementation of the 'Turkmenistan-Afghanistan-Pakistan-India' natural gas pipeline (TAPI) program. Russia is focusing on using and expanding the existing oil and gas transportation capacity and ensuring that it will have the largest share of new development projects. The EU is proposing the Central Asian 'new strategy' and Nabucco natural gas pipeline project, trying to get rid of its dependence on Russian natural gas. The United States has always had the attitude that China's entry into Central Asia must be contained, while Russia has also been doing everything possible to block China's interests in Central Asia. Against such containment from both Russia and the United States, China has exerted its comparative advantage by seeking development opportunities and achieving breakthroughs in spite of the difficulties. China successfully acquired PK (in 2005), completed the Kazakhstan oil pipeline (in 2005) and the Amu Darya Right Bank project (in 2008), acquired the Mangistau project (in 2009) and constructed the China-Kazakhstan, ChinaTurkmenistan and China-Uzbekistan natural gas pipelines; thus, achieving remarkable results in the competition for Central Asian resources and greatly enhancing its status in the energy political structure in Central Asia.

\subsubsection{Hidden risks in the political systems of Central Asian} countries

1) The current presidential systems have their hidden political risks. Executive powers of presidents become highly concentrated during political transitions; the function of the parliamentary systems are limited, and the multi-party systems are more virtual than real. These factors severely weaken the region's balancing mechanisms pertaining to the three separate powers (Song, 2005).

2) Regime changes, which are the most serious political risks faced by the Central Asian countries, can bring about social unrest. For example, the Kyrgyzstan regime change caused some of the local people to riot against Chinese personnel and shops, resulting in a huge amount of property damage and casualties.

3) New political forces possibly lead to political crises. Central Asian countries are in a state of social transformation, where their people are generally at a loss. Emerging political forces are seriously threatening political stability.

4) Differentiation of social structures often becomes the inducement for political instability. Central Asian countries have witnessed the so-called 'new rich class' and 'new trapped class' which fail to coordinate social and political interests in the normal way. People are likely to engage in a variety of radical behaviours in order to impose external pressure on the political system. This is a threat to political stability.

\subsubsection{Frequent extreme violence, rampant terrorist activities and social security deterioration}

Extremism is the main threat to Central Asian political stability (Vorobyov, 1991). Central Asian countries suffer from an imbalance in economic and political development, which usually results in the birth and spread of extremist forces, which include religious and extreme nationalism and terrorism. Frequent suicide bombings, armed assault and other serious incidents, along with an increase in religious extremist violence, seriously impact social security.

\subsubsection{Central Asian policies for national resources are gradually tightening and frequently changing}

With the transformation from privatization in the last century to nationalization and changes in the law, Kazakhstan has increased the control of its resources. Uzbekistan has laws and regulations that suffer from a lack of transparency and stability, increasing the risk of investment and trade in Uzbekistan. Turkmenistan has repeatedly amended its Oil-gas 
Resource Law, strengthening the president's absolute control over resource development and improving the position of the Ministry of the Oil and Gas Industry and Mineral Resources in foreign economic cooperation (Zhang, 2007).

\section{Conclusions and suggestions}

\subsection{Conclusions}

1) Central Asia is rich in oil and gas resources, with crude oil and natural gas remaining reserves accounting for $1.9 \%$ and $10.6 \%$ of the world's total remaining recoverable reserves.

2) Central Asia has a prominent geopolitical position. Major political and economic forces have intense competition for Central Asia's energy and strategic positions, and there are some strategic opportunities for China.

3) Through unremitting efforts over the past dozen years, CNPC has constructed a 50 million tonne per annum oil and gas production centre in Central Asia and the China-Central Asia multinational oil and gas pipelines. In 2015, oil and gas exports to China will be 70 million tonnes oil-equivalent and will become China's most important and secure energy import channel.

4) Although faced with multiple challenges, ChinaCentral Asia oil and gas cooperation has a large potential for improvement and the ability to construct a 100 million tonne oil-equivalent p.a. oil and gas production centre and a strategic pipeline channel to transport 100 million tonnes of oil and gas to China every year.

\subsection{Suggestions}

\subsubsection{Developing a clear energy acquisition strategy and establishing a regional energy ambassador}

International energy competition is essentially a competition between countries. China-Central Asia oil and gas cooperation is not just a corporate collaboration but also cooperation between governments to promote bilateral relations. Large oil and gas projects need vigorous promotion from national policy and through diplomacy. In order to develop a clear overseas energy acquisition strategy, China should regard 'the Silk Road economic belt' as an opportunity, constantly promoting a 'comprehensive strategic partnership' with Central Asian countries. According to the principle of 'mutual benefit', it is necessary to strengthen Central Asian energy diplomacy and promote cooperation for large-scale oil and gas projects and to take appropriate measures in terms of investment and aid policies. Currently, the United States, Russia and EU have energy ambassadors in Central Asia who serve as their chief coordinators in this region. It is therefore necessary for China to establish an energy ambassador in Central Asia, as well as energy advisors at the embassies, in order to coordinate the bilateral and multilateral situations that are diversified and complex.

\subsubsection{Establishing a risk prevention system}

It is necessary to further enrich our understanding of the Shanghai Cooperation Organization (SCO) cooperation, focus on the SCO platform, establish a win-win cooperation for energy as the starting point, improve cooperation in achieving the SCO energy security goals, ensure the interests of energy cooperation between members and maintain a 'moderate share' to prevent nationalism within the Central Asian countries and mitigate Russia's anxiety.

It is necessary to strengthen energy cooperation between the SCO countries by coordinating the energy policies of all parties, constructing regional public facilities and raising funds and implementing and formulating uniform rules and pricing mechanisms, including the following: 1) accelerating bilateral and multilateral energy cooperation in building institutions; 2) gradually establishing the SCO energy trading market; 3) improving energy cooperation between the member states and 4) establishing early-warning and defence mechanisms.

\subsubsection{Adhering to growth by mergers and acquisitions}

Growth by mergers and acquisitions is an important means to maintain rapid growth (Zou, 2013). The US networking company Cisco is a typical case of growth by mergers and acquisitions. After it was listed, Cisco conducted 174 mergers and acquisitions with a total investment of 60 billion yuan. The success of its mergers and acquisitions has made Cisco a leader in each of its involved fields. To develop the market overseas, Chinese enterprises such as CNPC should take this mergers and acquisitions strategy, expand their businesses in Central Asia and even globally, and thereby improve the internationalization level of corporations.

\subsubsection{Establishing multinational subsidiaries in Central Asia}

On the basis of the establishment of the corporate entity known as the CNPC Kazakhstan Company, it is necessary for CNPC to establish multinational subsidiaries in Central Asia, so as to achieve an optimal allocation of resources, form overall advantages and completely change the passive situation of the separate Central Asian projects. The roles of the company include the following: 1) coordinating public relations with the governments of the countries hosting the resources and their partners; 2) conducting overall planning and development of the oil and gas business as well as developing and implementing business strategies and deployment; 3) coordinating Central Asian human resources, planning and financial management, as well as technical and legal support; 4) coordinating Central Asian oil and gas production, deploying oil and gas resources, constructing and operating oil and gas strategic channels and developing new projects and 5) coordinating Central Asia health, safety and environment (HSE) efforts and counter-terrorism.

\section{References}

Bo Q L and Liu G Z. Central Asia geopolitics and opportunities of Chinese oil enterprises. International Petroleum Economics. 2012. 10 (11): $35-41$

BP Statistical Review of World Energy Jun 2013 [EB / OL]. Http://www. bp.com/content/dam/bp/pdf/statistical- review / statistical_review_ of_world_energy_2013.pdf

Gao F. China's "Westward" Strategy and China, the United States and Russia Central Asia Game. Diplomacy (Journal of China Foreign 
Affairs University). 2013 (05): 39-50

He W Y. Practice and Innovation of CNPC-Central Asia Oil-gas Cooperation Demonstration Zone. Internal Data of PetroChina Consulting Center. 2013

IEA. World Energy Outlook 2010. Paris: Organisation for Economic Cooperation and Development International Energy

Kou Z. A new pattern of oil and gas exports in Central Asia. International Oil Economics. 2010. (5): 39-47

Liang C. Central Asia Game New Perspective. Beijing: Social Sciences Academic Press. 2011

Mao H Y. Prospects of energy cooperation between China and Russia and 5 Central Asian countries. Progress in Geography. 2013. 32 (10): 1433-1443

Song D X. Five Features of Central Asia Geo-strategy. Contemporary International Relations. 2005. 16 (2): 3-5
Vorobyov. Central Asia-Next Target for Extremists. The Independent. 1991

Wang H Y. New Geo-economics-China and Central Asia. Beijing: World Affairs Press. 2012

Wang J R. Distribution of Central Asia oil-gas cooperation projects. Internal Data of CNODC. 2012

Zhang X H. Analysis of Central Asia energy policy and countermeasures. Journal of Yangzhou University. 2007. 11(1): 18-13

Zhao C Q. Power game and position of Central Asian countries. Journal of Xinjiang Normal University (Philosophy and Social Sciences). 2012. 35(2):71-74

Zou X: Multi-level Capital Market Development. Training Materials of Independent Directors of Listed Companies. 2013

(Edited by Zhu Xiuqin) 